\title{
Da'wah Generate the Arts of Malay Heritage in Terengganu
}

Berhanundin Abdullah'
Badlihisham Mohd Nasir²
Ahmad Syukran Baharuddin²
Aminuddin Hehsan²
Akmaliza Abdullah²
Adibah Muhtar2
Mohammad Azhar Mat Daut ${ }^{2}$
Mohd Nasir Ripin²
Abdul Basit Samat@Derawi2
2Faculty of Islamic Civilisation, Universiti Teknologi Malaysia, Skudai, Johor, Malaysia

Doi:10.5901/mjss.2016.v7n3s1p144

\section{Abstract}

Islamic Da'wah has grown in Terengganu began before the year 1303 AD missionary in extended periods of time, has managed to adopt Islamic values in Malay heritage. The purpose of writing this article is to detail the findings of research against some artistic practices that have been absorbed by Islamic art. This study uses text analysis method (content analysis) and documentation review and then processed in a descriptive writing. Analysis carried out on the facts of history and current information related to the practice of the arts in the community. The outcomes of this study verify that the application of Islamic values could change the Malay traditional arts heritage. Limitations of this study focuses on Malay language Jawi writing, learning the Quran, architecture, calligraphy, crafts and martial arts in the state of Terengganu. The impact of this study is able to enlighten the community that is very important to know the art heritage from the Islamic perspective and appreciate the art of Malay heritage.

Keywords: Da'wah, Islamic value, Malay heritage arts, Terengganu, Islamic Knowledge

\section{Introduction}

History of arrival of Islam in the Malay countries, especially in Terengganu has led the evolution of Islamic civilization in the arts. The role of Islamic missionary began before the year 1303 AD based on the Inscribed Stone inscription dated Rajab $702 \mathrm{AH}, 4$ to February 22, 1303 AD. The role of missionaries has brought changes to the growth of the arts and the importance of knowledge, ethics and aesthetics in art. Scholars and preachers use artistic approaches appropriate to the situation of life to be able to change the understanding of society and mentality. The Islamic missionary used softer approach, beauty and attractiveness in an effort to form a noble soul and noble character. Some Islamic art was absorbed in traditional Malay art. Among them are slavery value, the value of beauty related to the concept of divinity, the value of good character and piety, all these values was applied in heritage art to produce serenity, beauty, gentleness and self-confidence. The value of ethics and aesthetics is to complement to the value of Divinity.

The Islamic missionary absorbed the Islamic values in the field of art gradually in accordance with the appropriateness of the time and circumstances. Missionary effort was not to rush in changing society's mentality which is influenced by the myth and superstition. Hence, the missionary implemented through art is important efforts in presenting the message of Islam to eliminate the myth, superstition and the practice of disobedience. These missionary efforts must be continued to preserve the heritage of the Malays in the implementation of Malay-Muslim art.

Acceptance by part of Malay generation against the Malay heritage in Terengganu is not acceptable. They are 
exposed to the foreign art and culture which is influenced by the culture of hedonism where the effect is to give the purpose of entertainment and pleasure the human passions. Understanding and knowledge of the present generation related to the heritage art somewhat limited to the traditions of art and art-cultural entertainment such as Main Puteri, Mak Yong, Ulik Mayang and Silat (martial arts). This study is also very important to restore the glory of Islamic civilization in the arts which absorbed in Malay heritage art in integrated processing between the values of ethics, aesthetics and spirituality. The limitation of this study is focused on Malay heritage is still practiced in Terengganu.

\section{Discussions}

\subsection{Missionary Goals}

Studies on missionary responsibility in order to transform the Malay art, turned to Islamic art heritage feature are part of the Islamic missionary function. Missionary goals in the arts are to change the ignorance's nature and switch to Islam feature. This study describes the development of missionary gradually to dominate the situation and the opportunity to change the mentality of a community that is deeply rooted in the arts of Hindu-Buddhist influences. Islamic Da'wah is also confronted with the challenge of custom and traditional culture, which practiced from generation to generation as traditional practices and animism. At the present time also the community of Terengganu began to be influenced by modern art that could because they forget about the nation's heritage.

Recently, a missionary approach focused on community interest in artistic heritage is becoming less practiced in the Malay community under the influence of modern art, which has a background of entertainment, excitement and satisfaction. Therefore the fineness and beauty of inheritance should be developed as a missionary activity such as learning Quran with rhythm (tarannum), Arabic term retention in the teaching of knowledge and arts heritage or the main event with the community.

This study also points to re-establish the public's consciousness about the inheritance of great significance in meeting the demands of the entertainment. The elements of Islamic art are on display at one time to be seen continuously in public spirit. This exertion is worth it to make art preserved. The identity of the Malay arts be permeated by the faith via Islam and have been processed based on the Quran and al-Sunnah must be preserved. Retention Malay heritage represents the prosperous civilization of Islam in shaping world civilization. The rapid growth of the industrial sector of the arts, the maturation of data technology and changes in societal attitudes should be in line with the evolution of the Malay heritage of Malay identity. Missionary role should be enhanced to uphold the Malay heritage in Terengganu to the knowledge of the entire community.

\subsection{Missionary through the Arts}

The growth of Islam in the land has brought it some changes in all prospects of spiritual, physical and thinking. Missionary delivered by scholars and preachers either from Arabia, China, Persia or Malay Lands, have adapted to the fineness of the soul of society. Conscientiousness against missionary service has been able to influence the psyche and become the driving force to the moral values of Islam in the Malay heritage arts. Missionary methods of applying the finest values and ethics of aesthetics in Malay art have been an attraction and accepted by all strata of society. Missionary efforts in this study known as evolutionary art. It is carried out gradually and carefully in order to be capable to influence the mentality and mindset of the society. Islamic art more suited to the lifespan of the Malay community who are courteous and receptive to reform.

The Islamic missionary successfully implemented Islamic values gradually in Malay art began in the 11th century $A D$ until achieving the pinnacle of brilliance in the 16th century AD. Especially in the context of the evolution of Malay literature was developed through the Islamization of the Malay language, the terminologies Arab/ Persian-Islamic, Jawi writing, the art of reading the Quran, the art of Malay culture, art of Malay civilization and martial art as a direct result of the missionary (diffusion of Islamic teaching). A view of the Malay-Muslim art is discussed in an orderly manner in accordance with the historical development of Malaysian art.

\subsection{The Islamization of Language and Terminology}

Granting to the opinion of Syed Muhammad Al-Attas Naquib that the arrival of Islam in the Malay Archipelago, has caused Malay language follow undergoing the process of Islamization (1969:12). This process as an artwork to enable people to take the Islamic teaching and knowledge perfectly. Malay language is the medium for the teaching of Islamic 
knowledge and religious studies in the entire part of the Malay land, in addition to using the terminologies as well as Arab I Persian-Islamic. Many Arabic words have been used as a Malay word for facilities understanding and practicing the Islamic teaching. For example, iman, taqwa, insan, solat, haji, zakat, ikhlas, sabar and else.

Malay language previously was produced to be a limited, but after the arrival of Islamic teachings it has become the lingua Franca for expanding Islamic missionary and knowledge for the whole of the Malay community. While the solid sphere of cognition, particularly in relation to Islam and Malay civilization are written and elaborated in the Malay language through Arabic-Jawi inscription (Harun Mat Piah et al. 2000:37). Jawi inscription managed to take some form of calligraphy in handwriting. It is carved out and written either on the stone, wood, paper, animal hides and cloth.

Lettering styles of Jawi inscription which found in the literature of Malay myth stories influenced by Arabic style. Authors or the translators are often taking the terminologies and use words or phrases in Arabic. Writing inscriptions are not experiencing the difference because Jawi writing and Arabic inscription have the same form. In addition, there are many elements of the fiction influenced by oral stories and most of it is the beliefs of the Shia. The example of Malay Epic Stories is Hikayat Nur Muhammad (Ali Ahmad and Siti Hajar, 1996:2)

\subsection{Jawi as A Handwritten Calligraphy}

Some other issue of the development of Malay as a consequence of the implementation of preaching is the utilization and adaptation of the Arabic script to be the Jawi script to spell the Malay language. Jawi script is no different from the original form the alphabets of the Quran which has capital value in its own right. The effects of the Jawi script sketched in various figures have attracted the attention of anyone who looked.

Missionary activity is a very great contribution to the expanding Islamic knowledge in Malaya because has maintained Jawi writing, in the writing of literary, religious books, citizen's literature, history, law, classical prose and poetry as well as writing in artifacts. Important historical material about the date of arrival and the patterns of Islamic art in Terengganu was immortalized in the Jawi script. This is evident in Jawi script, are carved on the Batu Bersurat that has been set up in Kuala Berang, Terengganu dated $702 \mathrm{H}$ or $1303 \mathrm{M}$. This Jawi script was adapted to the Malay word and added five alphabets in the same form, but distinguished by the additional points for completing pronunciation. Some of his alphabets are nya, cha, nga, gha, and pa.

For more than 710 years, the Jawi script became the official script in Terengganu since the 13th century AD until mid-20th century, coinciding with the evolution of the Malay language which is the Lingua Franca language, in the Malay world. At that time, European traders, Chinese and Indian were coming to trade in the Malay world use Malay language as a medium of instruction and accept the Jawi script as the official script. Whole figures of agreement, document, consent commerce and the letters on official government as a business relationship with foreign merchants are written in the Jawi script.

The missionaries who came from Arabia have taught the Malay community to recognize Arabic letters in learning to read the Quran. Based on this learning, they are taught to say the Malay word on makhraj and then write in Malay pronunciation. Eventually Malay scholars created Jawi alphabets by using the form of Arabic letters in addition, some modifications and additions made by reference to the Malay language. The Jawi alphabets were created as replace Kawi letters and Nagari letters are derived from Hindu civilization (Winstedt and Wilkinson 1961:139).

Introduction of Jawi alphabets has been prompted missionaries to intensify efforts to extend the knowledge of Islam in the Malay language. The use of Jawi writing at an early stage is to explain the rudiments of Islam like the concept of Divinity and the principles rites of islam. Writing the religious books is known as a literary text script. The birth of the book literary is through writing and translation of religious texts that originated from Arabic (Harun Mat Piah et al. 2000:393). Universality in the Malay Jawi writing was diffused into the early education system in Malaya.

Jawi writing has been promulgated as Malay writing. The use of the Malay language written in Jawi officially as enshrined in the letter of appointment of each officer and the state laws such as the law of Terengganu set for 1911 (the Constitution of Terengganu 1911). To ensure that this agenda is reached, the Terengganu state government on the order of Sultan Zainal Abidin III in 1911 has issued the following instructions:

"..... and all letters relating to the office should be use lettering in Malay word" (Arkib Negara Malaysia, S. T. 209 / 1357).

\subsection{Art and Rhythm of Reading the Quran}

The expansion of Islamic missionary gets, the more rapid and interesting when correlated with reading and an 
appreciation of the Quran. In the early stages, the development of Islamic missionary among the public through learning of the Quran and religious knowledge are conducted in mosques, surau, stations, madrassah or homes. Therefore, the learning system has made an establishment called "Tok Guru", which is normally treated by the priest or preacher has to do with religious teaching. Quran learning system and religious are conducted in Tok Guru houses and this practice is cultural heritage in early stages of education (Shafie Abu Bakar, 1997:8). Munshi Abdullah's during his visit to Terengganu was admiring the beauty of Jawi writing / Arabic and elegance of the Quran recitation (Shafie Abu Bakar. 1997:4).

According to Munshi Abdullah, in his notes during a voyage to the East Coast of Malaya on Dzulhijjah until Muharam corresponding to 4 March 1253 until April 1838 and was stopped in Terengganu. He said that Terengganu community at that time reading the Quran very well up to renowned outside the state of Terengganu (Abdullah bin Abdul Kadir Munshi, 1965:32).

Learning Quran recitation was conducted by routine teacher, according to their free time, ordinarily in the late afternoon and evening. Only teachers of the Quran alone can teach the Quran because they have the pronunciation methods and the recitation fluently. At the beginning the students are instructed to recognize letters, recitation style, a situation to break off and connecting the sentences. Then taught the methods of Quran recitation with the rhythm according to the tone which adjusted with the meaning of a sentence.

\subsection{Calligraphy of Art and Khat}

According to scrunity Syed Muhamma Al-Attas Naquid that Malay inscription in Jawi script is the oldest untraceable in Malaya was found in Kuala Berang, Terengganu. It was dated on Friday, 4 Rajab in $702 \mathrm{AH}$ corresponding to 22 February 1303 AD (Gang Giong Sok, 1990: xxiii).

Batu Bersurat in Terengganu showed a strong evidence that the Malay Jawi writing was influenced by the Arabic. Jawi spelling system is a combination of Arabic orthography use, l'rab system (change of line markings; dhammah - row forward, fathah - top row, kasrah - the bottom line and sukun - sign off, according to its position in the sentence based on Arabic grammar) with the use of alphabets alif, wau and ya in the Malay language. These alphabets are known as vocal signs. Apart from that there are also signs of semi-vocal and diphthongs. Then followed the use mad and tasydid was first introduced (Muhammad Fauzi Jumingan, 2004:26).

The most popular calligraphy writing in the Kufa city (the capital of the Islamic Empire in the time of Saiyidina Ali bin Abi Talib) is Kufi calligraphy. In Malay, calligraphy used in the inscription was influenced by Kufi calligraphy as in Phan-Rang and Gerisik and then, came the khat Naskhi for copies of the Quran. Calligraphy continues to grow wider and there appeared a new type of khat Thuluth, Riq'ah, Diwani Jali, Raihani, Ta'liq Pharisees, thuluth Jali and other styles (Amat Juhari Moain, 1996:119).

Batu Bersurat of Terengganu has created in the form of khat - $7 \mathrm{M}$ century. Beginning of the century, during the Umayyad government establish calligraphic script until it reaches perfection in the final formation $-9 \mathrm{M}$. By extension, various forms of khat were produced, such as Nasakh, Diwani, Thuluth, Riq'ah, Raihani and some other calligraphy. But the Thuluth trend is running toward the Muhaqqaq and Raihani.

\subsection{Art of Sufi}

The evolution of Islam in Malay land was through the flow of Sufism and spirituality. Missionary from this path will attract more Malay community in studying the Islam because it emphasizes the moral and spiritual formation. For example, in Kitab al-Luma' include that the Sunni Tasawwuf has developed extensively. The content of Sunni Tasawwuf in the Kitab al-Durr al-Manzum was influence by combining with the teaching of theology from Sunni Asy'ari, tasawwuf Sunni alGhazali and the practice of sharia from Sunni Syafie (Harun Mat Piah dkk. 2000:43).

The spread of this religious in various aspect of Islam, such as recite Quran, hadith, treatise about pillars of faith and Islam, law, knowledge of Tasawwuf, philosophy, morals and others (Zuber 1963:19-20). Teaching, practice and appreciation of Tasawwuf more focussed on the Faith to God and the character formation. Missionary Islamiah from teaching of Tasawwuf has success in developed the great soul and honestly can build the good character.

\subsection{Arts of Literature}

The art of literature in Terengganu was growing rapidly since in the 19th century. Sayyid Muhammad bin Zainal Abidin bin Hussain bin Mustaffa Al-Idrus (Tok Ku Tuan Besar), was a scholar from Terengganu has written many of Kitab. Among 
the form of poetry is Kanz al-Ula (life of Prophet), Sirah al-Nabawiyyah (History of Prophet), Jawahir al-Saniyyah, alDurrah al-fakhirah and Tahiyat al-Wildan. The work in opus is like Targhib al-Sibyan fi Hifzi 'Aqaid al-Iman, Diya' 'Uquud al-Durratain fi Tarjamat Kalimantain al Syahdatain', Mukhtasar, Sullam al-Tawfiq (Shafie Abu Bakar 1991:3-8). Honor and title to Tok Ku Tuan Besar in the mock of literature with the Islam oriented encourage the local historian call "Father of Literature, Terengganu".

The manuscript about the constitutional also was write in the Jawi like Kitab Adab Raja-Raja in Terengganu and Kitab Nasihat Raja-Raja di Istana Terengganu written by Wan Abdullah bin Haji Wan Muhamad Amin (Tok Syeikh Duyong)(Worawit Baru 2004:104-136). The longest history of poetry is the Syair Tawarikh Zainal Abidin which has 3335 duple, written by Tengku Dalam Kalsom binti Tengku Wook Khazaki in the years 1930 (Muhammad Yusoff Hashim, 1980:54). This poet was the longest due to the story of the reign of three Sultans who ruled the Terengganu. This writing as a continuance to the historiography in entire of the Malay world (Harun Mat Piah dkk 2000:329).

The discussion about the development of literary classic Malay history is many expressed by the researcher include from western like R.O Winstedt (1969:1), which state:

"Literature strictly came into being with the art of writing, but long before letters were shaped, there existed the material of literature, words spoken in verse to wake emotion by beauty of sound and words spoken in propose to appeal to reason by beauty of sense".

As recognized by the history that the tradition of writing only exist in the Malay literature after the present of Islam in the Malay culture. The results of treasure of writing and Kitab-Kitab (manuscript) include hikayat also help to prove these development. Al-Attas (1986:6-8) expressed based on the progress research by the researcher from western and eastern, that there is no such literary works in any collection in the world proven to exist before 1600 century.

Works of story greatly influenced the Malays soul especially in Terengganu. The spread of this story was brought from Riau, Johor and Pahang until reach at Terengganu through the castles institution or Malay king. This has been popular among the Terengganu Malay community (Harun Mat Piah and Siti Zainon Ismail 1986). The book about religious either in the form of faith, Sharia, moral or nazam form, poet and others has been crafted with a lot of reading material until it becomes the main reading material in community.

\subsection{Missionary Shape the Privileges of Malays Artistic Heritage}

The effort of Islamic missionary has success to improve the beauty, subtlety and attraction to the Malays art with application Islamic values. This art finally become the artistic heritage in Malay community. The Malay artistic heritage disclosed in the formal community event so it cannot be forgotten. The affirmation term of the heritage shows that the approach of missionary in doing the Malays art to fix the practice does not conflict with the faith of Islam. It is maintained and cherished due to have its own benefit, such as:

1. Contains valuable knowledge and provide the information of science ago.

2. Educate people to love the religion through the religious books.

3. Promote human to love the Islamic culture and literature.

4. To value that is used by the government or the people in the past in all circumstances, affairs, time or anywhere.

5. As the introduction of Malay community identity, especially in Terengganu.

\section{Conclusion}

The artistic heritage of Malay culture developed through the knowledge of implementation missionary in Terengganu is very interesting. Moreover, it is effective to bring an evolution in the society from jahiliyyah practices to the development of knowledge and appreciation of Islam. The subtlety of Islam artistic as described before showed able to seep into the instinct of every human being and a catalyst for changes in attitudes, emotions, endurance and growth of knowledge. The artistic practice according to Islam is not just practice but had become symbols of Malay art that successfully led the development of civilization community for Terengganu. The Malay heritage arts should continue to be developed in line with the development of Islamic missionary so that foreign art no longer have the space to influence people. 


\section{References}

Abdullah bin Abdul Kadir Munshi. (1965). Kesah Pelayaran Abdullah. Singapura. Malaysia Publications Ltd.

Ali Ahmad dan Siti Haja Che' Man. (1996). Sastera Melayu Warisan Islam. Kuala Lumpur: Dewan Bahasa dan Pustaka.

Amat Juhari Moain. (1996). Sejarah Aksara Jawi. Kuala Lumpur: Dewan Bahasa dan Pustaka.

Arkib Negara. S.T. 114/ 1326. Terengganu: Arkib Negara Cawangan Timur.

Arkib Negara. S.T. 209/1357. Terengganu: Arkib Negara Cawangan Timur.

Al-Attas, Syed Muhammad Naquib. (1969). Preliminary statement on a theory of the Islamization Of the Malay-Indonesia architecture. Kuala Lumpur: Dewan Bahasa dan Pustaka.

Al-Attas, Syed Muhammad Naquib (ed). (1986). Hujjat al-Siddiq Li Dafi al-Zindiq. Kuala Lumpur: Kementerian Kebudayaan, Belia dan Sukan.

Gang Giong Sok. (1990). Perkembangan Tulisan Jawi Dalam Masyarakat Melayu. Kuala Lumpur:Dewan Bahasa dan Pustaka.

Harun Mat Piah dan Siti Zainon Ismail. (1986). Lambang Sari - Tari Gamelan Terengganu. Kuala Lumpur: IBKKM Universiti Kebangsaan Malaysia dan Pejabat Setiausaha Kerajaan Terengganu.

Harun Mat Piah., et all. (2000). Kesusasteraan Melayu Tradisioanl. Edisi Kedua. Kuala Lumpur: Dewan Bahasa dan Pustaka.

Hashim Haji Musa, (1999). Sejarah Perkembangan Tulisan Jawi. Kuala Lumpur: Dewan Bahasa dan Pustaka

Hashim Musa. (2003). Epigrafi Melayu: Sejarah Sistem Tulisan Dalam Bahasa Melayu. Cetakan Ke-3. Kuala Lumpur : Dewan Bahasa dan Pustaka.

http://www.angelfire.com/ma/drkang/jawi/dewanbudaya.html

http://ms.wikipedia.org./wiki/Tulisan -Jawi\#Pautan -Luar

Jones, Russel. (1983). The Origin of Malay Manuskript Tradition in European Colloquium on Malay and Indonesian Studies.

Muahmmad Fauzi Jumingan. (2004). "Pengaruh Bahasa Arab Dalam Tulisan Jawi". dalam Dewan Bahasa, April Jilid 4 Bilangan 4. Kuala Lumpur: Dewan Bahasa dan Pustaka.

Muhammad Yusoff Hashim. (1980). Syair Sultan Maulana. Kuala Lumpur: Penerbit Universiti Malaya.

Perlembagaan Negeri Terengganu, (1911). Itqan al-Muluk bi Ta'dil al-Suluk. Kuala Terengganu: Kerajaan Negeri Terengganu.

Shafie Abu Bakar. (1991). "Seminar Antarabangsa Kesusasteraan Melayu II, Bangi: Universiti Kebangsaan Malaysia.

Shafie Abu Bakar. (1997). Sejarah Terengganu Dulu Dan Sekarang. Terengganu: Lembaga Muzium Negeri Terengganu.

Winstedt, R.O. dan Wilkinson, R.J. (1961). Pantun Melayu. Singapura: Malay Publishing House.

Winstedt, R.O. (1969). A History of Classical Malay Literature. Kuala Lumpur: Oxford University Press.

Worawit Baru @ Haji Ahmad Idris. (Pynt). (2004). Pemikiran Melayu: Tradisi dan Kesinambungan. Kuala Lumpur: Dewan Bahasa dan Pustaka.

Zuber Usman. (1963). Kesusasteraan Lama Indonesia. Jakarta: Gunung Agung. 